\title{
Dormant Dispositions, Agent Value, and the Trinity
}

\author{
Samuel R. Lebens \\ University of Haifa \\ Dale Tuggy \\ Independent Scholar
}

\begin{abstract}
In this paper we argue that the moral value of an agent is determined solely by their dispositions to act intentionally and freely. We then put this conclusion to work. It resolves a putative moral paradox first posed by Saul Smilansky, and it undermines a prominent line of argument for a variety of Trinitarian theology. Finally, we derive our conclusion about the moral worth of agents not only from our initial series of thought experiments, but also from Abrahamic theism itself. This means that Smilansky's paradox can only possibly be rehabilitated by an atheist, and that the aforementioned line of argumentation for the Trinity is radically self-undermining, since it relies upon the denial of a corollary of Abrahamic theism.
\end{abstract}

\section{Justinia and Disposinia}

Suppose that we organized a society in the most just and sensible way possible. Imagine that peace is achieved, poverty is nearly eliminated, education is available to all, crime is extremely rare, and the justice system is almost always just. Call this place "Justinia." It would seem that in Justinia, there is rarely (if ever) any need for acts of great individual sacrifice or courage. Acts of great charity are almost never needed, because society runs as it should. Moral courage in the face of tyranny is never called for, because tyranny never arises.

Compare this society with another one. The land of Disposinia is outwardly indistinguishable from Justinia. Every citizen in one has a doppelganger in the other. Their respective histories unfold exactly in parallel. There is only one difference between the two situations, and it isn't a difference that any human observer could discover. The difference is this: although neither of them affords its inhabitants the opportunity for much sacrifice or courage, in Disposinia there are at least some inhabitants who truly have the disposition, should the right circumstances arise, to sacrifice greatly for others, and to display tremendous courage in the face of tyranny. They have these dispositions, even though they are never in fact actualized.

Perhaps each member of each society thinks of herself as disposed towards acts of moral grandeur. But everyone who thinks this of themselves in Justinia is wrong. If push came to shove in Justinia, which, thankfully it never does, no one would

Journal of Analytic Theology, Vol. 7, June 2019

10.12978/jat.2019-7.180004110424

(C) 2019 Samuel R. Lebens and Dale Tuggy • (C) 2019 Journal of Analytic Theology 
have the moral mettle to sacrifice greatly for people in need, or to show courage in the face of evil. In Disposinia, by contrast, some of the inhabitants really do possess the relevant dispositions, even though they remain forever dormant. ${ }^{1}$

An ordinary observer wouldn't be able to tell Justinia from Disposinia. Only if the inhabitants of both societies were thrust into some sort of moral test, would we be able to tell the two apart. Since these tests never arise, no one will ever discern their differences. And yet, it should seem obvious to anyone that the relevant citizens of Disposinia, because they possess the relevant dispositions, are better than their counterparts in Justinia. ${ }^{2}$ This seems true even though the citizens of the two worlds can't be distinguished by their actual behavior.

One might think that the citizens of Disposinia, with the relevant dispositions, would be even worthier if they actually saved people from tyranny, or sacrificed for the needy. Of course, this opportunity never arises in their world. This might just be a case of bad moral luck; fate never hands them the opportunity to attain true moral

1 One might worry that no two societies could differ only dispositionally. Dispositions are generally thought to have causal bases. How could outwardly identical histories, unfolding in outwardly identical societies, provide sufficient causal grounds for such radically different dispositions? We respond: it is essential to the thought experiment that the two societies are outwardly identical, but they needn't be inwardly identical. The psychology, biology, and other causal factors that partly determine the dispositions of the citizens of the two societies, if indeed such causal bases are required to ground dispositions, need only be similar enough to have allowed for their outwardly identical histories. It is unlikely that the causal structure of two systems could overlap so perfectly in the scenarios we depict, whilst diverging so radically at physically fundamental levels of description. But we have no reason to think that it's impossible. The power of a thought experiment isn't undermined by the unlikeliness of the scenarios it describes, as long as those scenarios are possible.

Moreover, when talking about the dispositions of agents freely to act, you might anyway think it unwise to look for causal bases, be it to generate a "sure-fire" disposition, or even a "probabilistic" disposition, since you might think that the freedom of human agents places them at a remove from probabilistic and determining causes (for the sure-fire/probabilistic distinction, see Prior, Pargetter, \& Jackson (1982)). Indeed, you might think that agents themselves are the causes of their actions. But this doesn't mean that we can't talk about an agent's dispositions to act. It simply means that those dispositions shouldn't be cashed out in terms of their agent-external causal "grounds." Rather, an agent has a disposition to $\Phi$ iff, in all of the closest possible situations where the stimulation conditions for the disposition are met, the agent $\Phi^{\prime}$ 's. Providing we reject a counterfactual analysis of causation, our counterfactual analysis of an agent's dispositions will not undermine the notion of agent-causation.

Moreover, in the remainder of this paper, most of our philosophical interlocutors will be theists. At the very least, our theistic interlocutors should accept that our two societies could be outwardly indistinguishable, even while their citizens hold radically different dispositions. We say this because the theist should accept the possibility, however remote, that God could simply bestow good dispositions upon the fortunate citizens of Disposinia. The different dispositions of our two societies could, therefore, have a supernatural causal basis.

${ }^{2}$ Some philosophers, basing themselves upon work in the empirical sciences, are skeptical that human agents have determinate moral characters (see e.g., Vranas 2005). These questions, and the debates that they give rise to are fascinating. However, we think it safe to assume that human agents really do have moral characters, and that people really do have determinate dispositions to act morally, or immorally. Moreover, the primary intellectual interlocutors that this paper addresses share our assumption. Indeed, it seems to be a central component of all of the Abrahamic religions that there is such a thing as a moral character and that our religions call upon us to improve it. Many people of no religion would share our assumption too (and indeed, secular philosophical arguments for this assumption abound; see Kupperman 2001, Sabini and Silver 2005). 
excellence. But, they would be worthier, one may think, if their dispositions actually had the opportunity to bear fruit.

We hold that the preceding line of thought is mistaken. Raoul Wallenberg saved many Jewish lives during the Holocaust. It is thought that he saved up to 100,000 people. $^{3}$ It may be the case that his courage grew through the experience of saving lives, such that he didn't have the courage to save 1,000 Jews until he had saved 100. That is to say, acts of heroism often enable further and greater heroism. But, it didn't have to be that way. For all we know, Raoul Wallenberg's heroism was fully formed before the advent of the Holocaust, even if, until that point, it had been unactualized-a mere disposition. If this were so, then Raoul Wallenberg didn't become a better person by saving those lives; he was already a moral giant. All that happened was that his great moral stature, which had hitherto been hidden, became manifest for all to see. We are thus led to the central doctrine of this paper:

The supervenience of agent value on dispositions (SAVD)

The moral stature of an agent is determined exclusively by their dispositions to act intentionally and freely in morally praiseworthy ways.

This doctrine has a corollary:

\section{The agent value irrelevance of disposition actualization (AVIDA)}

Actualising a valuable disposition doesn't, in and of itself, make the agent worthier than they were in virtue of having the disposition to begin with.

The qualification "in and of itself" is important. It might be the case that actualizing a valuable disposition helps you to acquire new valuable dispositions. It might be the case that actualizing a valuable disposition held to degree $m$ can help you to acquire that disposition to a new degree, $n$, where $n>m$. But these are merely side-benefits of actualizing a disposition, and are contingent on human nature, or even, conceivably, on an individual human's background psychology. Moreover, it's plausible that these side-benefits can be acquired in other ways. Perhaps the imagination and a good education can foster ethical growth without a person ever having to be thrust into situations that call for real sacrifice. Actualizing a disposition doesn't add ethical value to the agent, in and of itself, even though it can sometimes bring about value adding side-effects, side-effects which could in principle be obtained by other means.

Reflecting on the difference between Justinia and Disposinia helps us to see how valuable dormant dispositions can be. Reflecting on the possibility of a fully formed Raoul Wallenberg, who at the outbreak of the Holocaust was fully equipped with the dispositions required to save many lives, helps us to see that actualising dormant dispositions isn't necessary for the the value of a moral agent. The

\footnotetext{
${ }^{3}$ https://www.history.com/topics/holocaust/wallenberg-raoul
} 
possession of valuable dispositions is all that is necessary for an agent to have moral value.

Someone might object as follows: ${ }^{4}$

Imagine a person who has never played basketball, but happens to have the fully formed physical and athletic dispositions to be a superb player, immediately upon being given a ball and told the rules - even without any training. To say that Raoul Wallenberg is no better a person for having actually saved lives would be equivalent to saying that this merely potential basketball player already deserves a place in the Basketball Hall of Fame, despite having no sporting achievements to his name. In actual fact, it is achievements, and not potential, however fully formed it may be, that we value. Do people who would have saved lives, given the opportunity, deserve medals and awards? Does a person deserve a Nobel Prize for potential in the sciences? Certainly not. And so the doctrine of agent worth, and its corollary, must be false.

We should not confuse the value of persons with the value of events (or circumstances, facts) which involve those persons. It is because we value certain events involving and brought about by certain agents that we induct those agents into the Basketball Hall of Fame. It is because we value certain items of knowledge, discovered by certain agents, and it is because we value their discovery, that we award those agents prizes for the sciences. Both of those institutions exist to celebrate actual achievements. But when we focus on the value of agents, rather than on the value of circumstances or events, we realise that good character traits, understood as dispositions to act, do all of the work; the moral worth of an agent supervenes on those alone.

We have the disposition to read to our children. Obviously, we're both better off for actually having children to read to, in addition to our disposition to read to them. ${ }^{5}$ We're not denying that. But, we're not better moral agents because we have children (at least, not without our having children altering our underlying dispositions); we're just better off. Agent value isn't the only species of value. Our having children is valuable, and it might be a case of good luck, but it isn't a case of moral luck.

Of course, we are very limited in our knowledge of people's dispositions; we don't always know how people would act in hypothetical situations. But it is those dispositions to act that distinguish good agents from bad agents. This is what would make a Good People Hall of Fame different from a Basketball Hall of Fame. While the latter celebrates actual achievements, the former would celebrate persons of great value, as determined by their tendencies to act. Again, given how humans are, any inductee of the Good People Hall of Fame will have become so by means of a stellar track record of courageous and determined moral actions, which have sculpted her character. But it is that character-those dispositions-which would qualify a

\footnotetext{
${ }^{4}$ We thank Saul Smilansky for raising this and the following objections in correspondence.

${ }^{5}$ Thanks to Michael Antony for raising this example with us.
} 
person; and, conceivably, a person just might be born with, or be supernaturally given, such dispositions.

It is important to see that agent and situation value can come apart. The devil himself, in a moment of weakness, may do something good, such as taking steps mercifully to relieve some innocent person's migraine headache. We would be delighted that this innocent person's headache was ended, and that the devil did this. Those situations (events, facts) are very good. But the value of those events don't contribute to an improved moral stature for the devil, not if they leave his dispositions unchanged. His overall dispositions may still be unimaginably vile. On the other hand, a real moral saint may in a moment of weakness and frustration verbally lash out at her child. That this happens is bad. But still, she may be a very good person - her overall dispositions may nonetheless be exceptionally good. Her lashing out makes no dent in her moral stature, unless the event changes her overall dispositions.

But perhaps the objector will press his case:

SAVD, and its corollary AVIDA, seem to imply that a person is no worse a person for committing a crime (in a circumstance of type $x$ ) than for having the disposition to commit that sort of crime (should $x$-like circumstances arise). Does this mean that we should be punishing people for dormant dispositions to criminal activity?

We don't punish people for negative dispositions. There are both practical and moral reasons for this. Practically, in all but the rarest cases, we can't detect dispositions to act, and so it would be futile to attempt to punish their possessors. Morally, we would not want to punish all such people, because, as we've noted already, they may or may not be to blame for having those dispositions - it would depend upon how they acquired them and/or what they've done to maintain them.

We all think that it is central to the moral life, given the condition we find ourselves in, that we resist many of our dispositions, whether to yell at our spouse, to steal what we can't afford, or to engage in cruel social exclusion of vulnerable people. The objection only seems to get traction because in fact we typically do make ourselves worse by acting on our bad inclinations. By giving into one's stealing impulses, one forms a habit of stealing; one changes from a person who is often tempted to steal into a thieving rascal. That is, by choosing to steal, you typically increase your own disposition to steal. Someone with God-like knowledge would be able to directly observe this change for the worse, a change of disposition.

We are making a conceptual point: the moral value of an agent supervenes on the totality of her dispositions intentionally and freely to act. We are not dealing with the practical aims of avoiding becoming worse people and succeeding at becoming better people, nor are we dealing with the notion of culpability, or the purposes of punishment.

The foregoing objections have failed. SAVD and AVIDA seem to be eminently worthy of adoption. These doctrines can be put to work in ethical theory and in analytic theology. In the latter, they undermine an argument for a version of trinitarian theology. In the former, they can help us to resolve a moral paradox advanced by Saul Smilansky. In the next two sections, we unpack these consequences. 


\section{Dormant Dispositions and the Trinity}

Most informed Christians believe the doctrine that God is three "Persons" on the basis of their readings of the Christian scriptures and/or on the basis of later Christian traditions. One of us, a Jew, simply does not accept the epistemic authority of Church teachings or Christian scriptures, while the other, a unitarian Christian, finds a conflict on this point between Christian scriptures and later traditions, and being a Protestant, he sides with the former.

Some Christian philosophers, however, have sought to advance a priori arguments for the Trinity which, if sound, ought to persuade both of us. Their thrust is that if a perfect being existed, this being would of necessity, in some sense, be three "Persons," or at least more than one. ${ }^{6}$ If this reasoning is correct, then Jews, Muslims, and unitarian Christians are unwittingly worshiping what would be, if real, a somewhat imperfect being. And if they agree with the method of perfect being theology, they'd be mired in the incoherent view that God is perfect and yet (because only one "Person") imperfect. But as we explain, to their peril, such arguments assume the falsity of $S A V D$.

A priori arguments for trinitarianism tend to move in two stages. ${ }^{7}$ At stage one they seek to establish that a perfect being couldn't be a solitary self. This leads us to conclude that God must be at least two selves, and hence that any unitarian theology is false. At stage two they seek to establish that God must be no more, and no less, than three selves, in order to arrive at trinitarianism. In this paper, we will only focus on the first stage.

One such argument has been advanced by Stephen T. Davis $(2006,65) .{ }^{8}$ It runs as follows:

1. Necessarily, God is perfect, and perfect in love.

2. Necessarily, if God does not experience love of another, God is imperfect.

3. Therefore, necessarily, God experiences love of another. [1, 2]

\footnotetext{
${ }^{6}$ In this paper we will not consider whether the doctrine is internally coherent, or whether it is consistent with biblical monotheism. We assume for the sake of argument that one God can somehow be more than one "Person."

${ }^{7}$ Some of the a priori arguments that we won't examine here are barely worthy of examination to begin with. One argument assumes that God cannot be happy if God is all alone, and that he would be less perfect if his happiness depended upon creatures that were not his peers. This argument trades in the most extreme form of naïve anthropomorphism, and in idiosyncratic intuitions about what it means to be perfect. Another argument asserts that it isn't possible to be a self without being related to others, which seems like an unsubstantiated and unlikely metaphysical doctrine. These arguments are well dismissed by Dale Tuggy (2015).

${ }^{8}$ We have changed the claim in Davis's premises 5 and 6 that "ST [Social Trinitarianism] is false" to the claim that "unitarianism is true" (i.e. that God just is a certain single Self). While Davis's original conclusion is that "ST is true," our version above concludes that unitarianism is false. In so doing, we've made his attempted indirect proof of ST into an attempted demonstration of the incoherence of any unitarian theology-surely a welcome step for one who would prove a Trinity doctrine from reason alone.
} 
4. Necessarily, it is possible that only God exists (i.e. that God does not create). [Given the orthodox doctrine that God's creation was free]

5. Necessarily, if unitarianism is true, there is no "other" in the godhead.

6. Necessarily, if God alone exists and unitarianism is true, then God does not experience love of another, and thus is not perfect. [2, 4, 5]

7. Therefore, necessarily unitarianism is false.

If we accept this argument as sound, then we have to accept that the perfect God in some sense "is" at least two selves, if not more. God must somehow contain two or more "Persons" who are capable of interpersonal love.

But even if you believe in the Trinity, you shouldn't accept this argument. The trouble starts with premise 2. Why should anyone believe it? Richard Swinburne $(1994,178)$ defends the premise, stating that, "The best love would share all that it had." Consequently, if God isn't to be forced into creating a world to share his love with, and if God is to enjoy the perfection of sharing and social integration that comes along with peer-love, then God the Father requires the generation of a second divine person, namely, the Son, outside of any act of creation (why these must be two of three is another story). Tom Morris advances the same sort of reasoning to support premise 2:

[I]n order to be a fully loving person, any individual must extend his or her love beyond the bounds of self alone. Divine love is not only complete, it is eternal and necessary, so there must exist on the part of God some sharing of love which is both eternal and necessary (1991, 177).

Premise 2 has been objected to on the grounds that "one can have the character trait of being fully loving without actually loving anyone beyond oneself" for instance, if nobody else existed. "From the fact that a being is loving, it doesn't logically follow that she actually loves, and it doesn't matter if we change this to completely or perfectly loving" (Tuggy 2015, 136).

Another way to see the implausibility of 2 is to consider parallel arguments based on other divine perfections.

8. Necessarily, God is perfect, and perfect in forgiveness.

9. Necessarily, if God does not forgive another, God is imperfect.

10. Therefore, necessarily, God forgives another. [8, 9]

11. Necessarily, it is possible that only God exists (i.e. that God does not create)

12. Necessarily, if unitarianism is true, there is no "other" in the godhead.

13. Necessarily, if God alone exists, and unitarianism is true, then God does not forgive another, and thus is not perfect. $[9,11,12]$

14. Therefore, necessarily unitarianism is false.

This argument, if sound, would prove that God must contain at least one sinner in need of forgiveness. Again, focus on God's perfect compassion. 
15. Necessarily, God is perfect, and perfect in compassion.

16. Necessarily, if God does not have compassion for another, God is imperfect.

17. Therefore, necessarily, God has compassion for another. $[15,16]$

18. Necessarily, it is possible that only God exists (i.e. that God does not create)

19. Necessarily, if unitarianism is true, there is no "other" in the godhead.

20. Necessarily, if God alone exists, and unitarianism is true, then God does not have compassion for another, and thus is not perfect. $[16,18,19]$

21. Therefore, necessarily unitarianism is false.

But do we really want there to be someone within God whom it makes sense to pity or to forgive?

These latter two arguments (8-14 and 15-21), we assume, are unwelcome. Yet, there is as much to say in favor of their second premises as there is to say in favor of the second premise of Davis's argument (1-7). In other words, all of them $(9,16$, and 2) are wholly implausible. A being might be perfectly loving, perfectly forgiving, and perfectly compassionate, even though there is no one else who might benefit from the exercise of these virtues. These are a trinity of unsound arguments.

One could try to resist the analogy we draw between Davis's argument and the others. Admittedly, a Christian will feel the need to affirm premise 1. The Christian

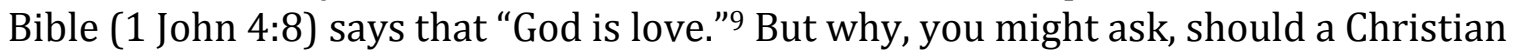
accept premises 8 and 15, the first premises of our two parody arguments? Certainly they will grant that God is compassionate and forgiving, but why should they grant that he is necessarily compassionate, and necessarily forgiving? ${ }^{10}$

We respond: one would have to have a very austere conception of perfection not to think that God's necessary compassion and forgiveness don't follow directly from his necessary perfection (like our interlocutors, who want to argue against unitarian theology based on their conception of divine perfection, we are here assuming that the method of perfect being theology is legitimate). If God is necessarily perfect, doesn't it follow that he's necessarily disposed to forgive and to be compassionate, and doesn't that make him necessarily forgiving and necessarily compassionate? This less austere conception of Divine perfection gels particularly well with Biblical presentations of God as somehow unique in his forgiveness and compassion (see Daniel 9:9), and in his goodness (Mark 10:18; Matthew 5:48).11

Our opponents might now contend that love is different from compassion and forgiveness, in virtue of the following argument: 12

22. Since God didn't have to create the world, predicates that require creation are not predicates that can be apt of God necessarily.

\footnotetext{
${ }^{9}$ The Christian co-author of this paper points out: nothing about this passage implies or even suggests that God must actually be loving another. The idea rather seems to be that God is the very paradigm of a loving being, that is, of someone with that important character trait, which is a disposition.

10 This objection was raised by an anonymous reviewer for this journal.

${ }^{11}$ Moreover, the Jewish author of this paper isn't going to be put off the force of our parody arguments by a verse from the New Testament (i.e., 1 John 4:8). More generally, one can't rebut a parody of a supposedly a priori argument, with considerations that are decidedly not $a$ priori.

${ }^{12}$ Again, this argument is derived from the comments of an anonymous reviewer for this journal.
} 
23. Forgiveness requires creation.

24. Compassion requires creation.

25 . Love does not require creation.

26. Therefore: neither "forgiveness" nor "compassion" can be apt for God necessarily, but "love" might be.

This argument fails to drive a wedge between Davis's argument and our parodies for two reasons. First: to assume that forgiveness and compassion require creation (i.e., 23 and 24) is to assume that they are perfections that are held, not in the dispositions to forgive and to care, but in the exercise or manifestation of those dispositions. This is just to assume the falsehood of SAVD and AVIDA (more on that below). Secondly: to assume that love doesn't require creation (i.e. 25) is to beg the question in favor of Davis. If your only reason for thinking that love, unlike forgiveness and compassion, doesn't require creation is that God is more than one loveable Person, and so has the ability to love before he creates, then you're merely assuming the denial of unitarianism.

As best we can see, there is no reason to prefer Davis's argument over our parodies. All three arguments go wrong at their second premise. Each of their second premises presuppose the falsity of SAVD and AVIDA. Accordingly, all three arguments contend that a unitarian God would be less great if he only existed by himself, with all of his perfect intrinsic attributes, and would somehow be more valuable if he had the opportunity to manifest them. Davis $(2006,66)$ makes this explicit:

It seems that a God who does not and cannot love another has missed out on something high and wonderful; there would be a deficiency in God.

We disagree. Not to be able to love, or, being able but not disposed to love, would certainly be deficiencies, but not loving another because there is no other to love, can only be regarded as a deficiency if one thinks that the mere disposition to love confers less value upon an agent than the exercise of that disposition. But we came to the conclusion in $\S 1$, for reasons independent of theology, that this is false. The moral value of an agent supervenes on that agent's dispositions to act.

We concluded in $\$ 1$ that our having children (if it doesn't alter our underlying dispositions) doesn't make us better people, even if it makes us somehow better off. In God's case, we might want to go further. Nothing can make him better. He's perfect. He was perfect before he voluntarily created the world. His moral perfection, it makes sense to say, was only a function of his dispositions.

It's tempting to think that a disposition expressed does confers more value upon an agent than the mere possession of that disposition, but that temptation derives from the fact that we human beings can never really be sure that we possess a disposition until it is tested and expressed. God, by contrast, can know that he has all of the best dispositions that are possible for an agent to have, even if, in his ontological solitude, some of those dispositions were to be forever left dormant.

Perhaps you're an advocate of divine simplicity. You might argue that this makes it impossible for God to have dispositions. We respond: if a simple God can 
have the property of love, perhaps in virtue of being identical to it, then we don't see how God's simplicity would rule out the possibility of his having the disposition to love, perhaps in virtue of being identical to it. We also note that the most prominent advocates of a priori arguments for the Trinity, such as Davis, William Lane Craig, and Richard Swinburne, deny the classical doctrine of divine simplicity to begin with. (Davis 2006 ch. 4; Craig and Moreland 2017, 530-532; Swinburne 1994, ch. 7-8)

A final worry: you might think that God cannot even have the disposition to love if there is nobody to love. The lack of somebody to love would, to use the terminology current in the literature, mask a disposition to love, just as being wrapped up in protective material would mask the fragility of a glass. A masked disposition, you might think, is no disposition at all (Johnston 1992). But we don't accept that the masking of God's pre-creation dispositions would render him, or his dispositions, any less perfect. Shungo Choi $(2006 ; 2008)$ and Lars Gundersen (2002) both argue that a glass in protective material still has the disposition to shatter, in that it has the disposition to shatter in the absence of its packing material. Similarly, God in his pre-creation solitude still has the disposition to love, in that he has the disposition to love should somebody exist to be loved.

Richard Swinburne (2008, 28-9) advances a similar argument to Davis's, according to which God the Father can only be considered perfectly generous if he shares his divinity with others (preferably, it turns out, he should share it with two others). We should worry about what it would mean for a God to share divinity with others, and whether this would collapse into a metaphysical absurdity (such as an entity sharing something that simply can't be shared, like identity or an individual essence), or whether it collapses into polytheism (Tuggy 2015). But we should also note that, once again, the argument only gets started if you think that God's generosity, when left dormant for lack of recipients, is somehow less marvellous than his generosity in action. We would respond: even unexercised generosity could be perfect generosity.

Reflection on Justinia and Disposinia helped us to see the truth of SAVD. Attempts to prove trinitarianism a priori tend to begin with an argument against unitarian monotheism. The thrust of such arguments is that a unipersonal God would be less perfect than a multi-personal God, in virtue of valuable dispositions which would be left dormant in the former case. Any such argument relies upon the negation of SAVD and AVIDA. The problem is that both of the doctrines these arguments negate seem to be true. Unitarian monotheism is untouched by these would-be philosophical proofs of the Trinity, which fail at their first stage.

\section{Dormant Dispositions and Moral Paradox}

Saul Smilansky claims to have discovered a paradoxical relationship between morality and moral worth. The need for heroic and sacrificial moral behaviour only arises, Smilansky notes,

when we encounter actual human suffering and grievous wrongs.... These in turn urge us to eliminate them as far as possible: 
they urge us to eliminate the circumstances responsible for suffering and wrongs. However, doing so would thereby reduce opportunities for achieving moral value $(2007,86)$.

Thus, on Smilansky's view, the dictates of morality encourage us to create societies like Justinia or Disposinia, in which moral demands are rarely (if ever) made of its citizens, because moral needs so rarely arise. This creates a strange relationship, which in Smilansky's terminology can be called an "existential paradox" $(2007,4)$, between moral demands and moral worth:

The purpose of true morality is to eliminate certain conditions (suffering and grievous wrongs). Yet only if those conditions exist can they call forth the moral actions that uniquely confer moral value. Paradoxically, morality is an "enemy" of moral worth. Valuable moral behavior ends up resembling one of those mythological animals that eat their own tails, thus putting an end to the very condition for their own existence $(2007,88)$.

But Smilansky's case is built upon the assumption that the citizens with valuable dispositions in Disposinia suffer from a case of moral bad luck for not living in a society in which their dispositions are given a chance to manifest. He claims that, "If people could really live their lives by sacrificing only very little for the sake of strictly moral concerns, a loss would be involved" $(2007,81)$. A loss for whom? You might think that there is a loss for the well-disposed agents who don't get a chance to manifest their valuable dispositions. These agents won't be able to attain their "true human nobility" $(2007,81)$. But we came to conclude in $\$ 1$ that this isn't true. A Raoul Wallenberg might never come to learn how morally worthy he is until he's tested, but the successfully navigated test itself doesn't play any necessary role in conferring his moral worth upon him. Consequently, Smilansky's case is built upon the denial of SAVD.

Smilansky $(2007,80-82)$ asks us to compare what he calls "the well-arranged minimal-morality world" (i.e., either Justinia or Disposinia), with an "ill-arranged unnecessarily morally demanding world" (i.e., a world where moral courage is sometimes called for and instantiated). Part of the paradox is supposed to be that it would be immoral to seek to transform a well-arranged situation into an ill-arranged situation, but that nevertheless the ill-arranged situation has some sort of unsurpassed human value that cannot be found in the well-arranged one; namely the opportunity for acts of great moral courage and sacrifice. Smilansky contends that there is some sort of loss incurred in the transition from an ill-arranged world to a well-arranged world.

We've established that if there is any loss in this transition it wouldn't have to be a loss of the moral worth of the agents in question. Perhaps there would be some other sorts of loss: the lost opportunity to act in certain ways for certain people, or the loss of a certain sort of beauty, but those losses don't affect our argument.

There is no paradox here because Smilansky is wrong to claim that "certain forms of [agent] value come into being only when people act in light of moral concerns under trying circumstances" $(2007,79)$. 
The moral value of agents supervenes only on their dispositions to act. Although moral sacrifice often does provide us-given human nature and circumstances-with an important moral training ground, enabling further moral growth, it seems metaphysically possible to form these dispositions even in the absence of opportunities to manifest them. And although moral sacrifice does in fact provide onlookers with tremendous inspiration, this benefit could in principle be reproduced with an imaginative ethical education. In sum, on the plausible assumption of $S A V D$, underwritten by compelling intuitions, we can see that there is no paradox here.

\section{Opening the door to Smilansky}

The family of a priori Trinitarian arguments addressed in $\S 2$ actually seem to open the door to Smilansky's ethical point of view. They assume that agent value has to supervene on more than dormant dispositions. Smilansky agrees. But it's hard to see that this should only be the case with the disposition to love, and not other valuable dispositions.

Abrahamic theists, we contend, shouldn't be willing to open the door to Smilansky's point of view on this issue, since his point of view rules out the possibility of an essentially perfect God who, existing all alone, has the ability freely to choose to create a world. In other words, Smilansky's point of view is incompatible with a central tenet of the Abrahamic faiths. Smilansky is an atheist and will not see this as a cost to his position. But theists should be wary of opening that door. To see this, consider the following argument:

1. Actualising a valuable disposition does, in and of itself, make the agent worthier than they were in virtue of having the disposition to begin with. [The denial of $S A V D$ ]

2. Suppose: It is metaphysically possible that: only God exists, and God has the ability freely to choose to create. [A tenet of Abrahamic religions]

3. It is not possible that God be worthier/morally better than he actually is. [Since God is perfect, he couldn't be better than he is]

4. Necessarily, if God creates a world with morally free agents, God thereby acquires new opportunities to actualize his valuable dispositions (e.g. to forgive, show compassion, keep promises, etc.). [Self-evident truth.]

5. It is possible that God be worthier/morally better than he actually is. $[1,2$, 4]

6. But this is a contradiction. $[3,5]$

7. Therefore, one or more of $1,2,4$ is false. [1, 2-6]

8. But 4 is self-evident.

9. Therefore, either 1 is false, 2 is false, or both 1 and 2 are false. $[7,8]$

The conclusion of this argument is that 1 or 2 (or both) should be denied. A Christian theist like Davis, Swinburne, or Morris, ought to prefer 2 to 1 . It is part of the Christian tradition, and arguably is provable, on the assumption of perfect being 
theology, that God doesn't have to create, but creates freely, and might not have created. Nor should a Christian urge that the argument is unsound by denying 3. A priori arguments for the Trinity tend to assume that God is perfect. 3 follows from that assumption. Our interlocutors should, therefore, find 3 more plausible than 1.

This argument shows the high theological cost of 1 . Either one accepts the argument as sound and denies 2, or one denies the soundness of the argument by denying 3. Neither is a cost worth paying merely in order to gain a purely philosophical proof of the Trinity (or refutation of any unitarian theism). Moreover, if the philosophical proof of the Trinity requires the claim that God is perfect, the denial of 3 , a denial that such a proof would require, seems bizarre in the extreme. How can one think that God is perfect but that he could also be more worthy than he is?

In $\S 1$, we sought to establish $S A V D$ on the basis of firm moral intuitions, independent of any explicitly religious commitments. It seems that $S A V D$ is also a consequence of Abrahamic theism, since any such theism is incompatible with the denial of $S A V D$. To the extent that a priori arguments for Trinitarianism rely upon the denial of $S A V D$, they thereby turn out to be radically self-undermining, since they eat away at the very foundation of Abrahamic theism.

SAVD and AVIDA are well-motivated doctrines, independently of theological considerations. They dissolve Smilansky's moral paradox. Furthermore, an Abrahamic theist cannot consistently deny SAVD and AVIDA. Accordingly, the arguments explored in this paper give us no reason to believe that a unipersonal God cannot be a perfect being. ${ }^{13}$

\footnotetext{
${ }^{13}$ Samuel Lebens would like to acknowledge that his research towards this publication was made possible through the support of a grant from Templeton World Charity Foundation, Inc. The opinions expressed in this publication are those of the authors and do not necessarily reflect the views of Templeton World Charity Foundation, Inc.
} 


\section{References}

Choi, S. 2006. "The Simple vs. Reformed Conditional Analysis of Dispositions." Synthese 148: 369-379. .2008. "Dispositional Properties and Counterfactual Conditionals." Mind 117: 795-841.

Davis, S. T. 2006. Christian Philosophical Theology. Oxford University Press.

Gundersen, L. 2002. "In Defence of the Conditional Account of Dispositions." Synthese 130: 389-411.

Johnston, M. 1992. "How to Speak of the Colors.” Philosophical Studies 68: 221-263.

Kupperman, J. 2001. “The Indispensability of Character” Philosophy 76: 239-50.

Morris, T. V. 1991. Our Idea of God: An Introduction to Philosophical Theology. InterVarsity Press.

Moreland, J. P. and Craig, W. L. 2017. Philosophical Foundations for a Christian Worldview, 2nd ed. InterVarsity Press.

Prior, E., Pargetter, R. \& Jackson, F. 1982. "Three Theses about Dispositions." American Philosophical Quarterly 19: 251-257

Sabini, J. and Silver, M. 2005. "Lack of Character? Situationism Critiqued." Ethics 115: 535-562.

Smilansky, S. 2007. Ten Moral Paradoxes. Blackwell Publishing.

Swinburne, R. 1994. The Christian God. Oxford University Press. 2008. Was Jesus God? Oxford University Press.

Tuggy, D. 2015. “On the Possibility of a Single Perfect Person.” In: Christian Philosophy of Religion: Essays in Honor of Stephen T. Davis, Edited by C. P. Ruloff. Notre Dame Press.

Vranas, P., 2005. "The Indeterminacy Paradox: Character Evaluations and Human Psychology" Noûs 39: 1-42. 